KrzyszTof GajeK

Akademia im. Frycza Modrzewskiego w Krakowie

\title{
OŚWIADCZENIA WOLI SKŁADANE W TOKU KOMUNIKACJI ELEKTRONICZNEJ A PRAWO PRYWATNE MIĘDZYNARODOWE - ZARYS PROBLEMATYKI
}

\section{UwAGI OGÓLNE}

Wzajemne powiązanie problematyki ustalania prawa właściwego oraz zagadnienia oświadczeń woli składanych w ramach komunikacji elektronicznej jest tematem, który już na pierwszy rzut oka rysuje się jako zagadnienie potencjalnie problematyczne. Nawet bowiem pobieżne spojrzenie na charakter korelacji zachodzącej pomiędzy tematyką prawa kolizyjnego a elektronicznymi metodami porozumiewania się ukazuje problem, do którego podejść można na dwa zgoła odmienne sposoby. Obydwa rzeczone stanowiska mają przy tym wspólny mianownik, a jest nim okoliczność globalnego zasięgu komunikacji elektronicznej. Powszechna dostępność błyskawicznej transmisji danych pomiędzy użytkownikami bez względu na miejsce ich przebywania skutkuje tym, że stosunki cywilnoprawne zawiązywane za pomocą cyfrowych metod porozumiewania się z jednej strony traktować można jako posiadające niejako z zasady swoisty „przymiot międzynarodowości”. Z drugiej strony ta sama okoliczność, a mianowicie globalny zasięg komunikacji elektronicznej, pozwala bronić poglądu, że specyfika funkcjonowania tejże komunikacji ma charakter nie tyle międzynarodowy, ile raczej ponadnarodowy i „pozaprzestrzenny”, a okoliczność „wędrówki impulsu 
elektrycznego" po całym świecie ma w tym kontekście charakter irrelewantny. Bez względu na sposób podejścia do rozwiązania rzeczonego problemu, który - choć pociąga za sobą określone konsekwencje - ukazany został jedynie jako przykład, nie ulega wątpliwości, że spojrzenie na komunikację elektroniczną przez pryzmat norm kolizyjnych jest zagadnieniem, którego doniosłość rośnie wprost proporcjonalnie do wzrostu popularności nowoczesnych metod porozumiewania się w obrocie gospodarczym.

Analizowanie przedmiotowego zagadnienia rozpocząć należy od podkreślenia, że z uwagi na jego złożony charakter ma ono związek z wieloma tematami pokrewnymi, zwłaszcza zaś z problematyką chwili złożenia oświadczenia woli w toku komunikacji elektronicznej oraz miejsca zawarcia umowy opartej na takich oświadczeniach, jak również sposobu i miejsca jej wykonania (np. online albo offline). Relewantne dla problematyki ustalania prawa właściwego dla czynności prawnych dokonywanych w ramach komunikacji elektronicznej mogą również być takie aspekty, jak kwalifikacja podmiotowa stron (np. umowa zawarta pomiędzy przedsiębiorcą a konsumentem) czy przedmiot danej umowy (np. w przypadku umów o świadczenie usług społeczeństwa informacyjnego należy rozważyć zastosowanie przepisów tzw. dyrektywy o handlu elektronicznym) ${ }^{1}$. Wszystkie te zagadnienia - pomimo że są w pewnym sensie pierwotne wobec tematu głównego niniejszego artykułu - stanowią jednak materię niezwykle obszerną i kwalifikującą się do ujęcia w osobne ramy badawcze, dlatego w niniejszym opracowaniu uwzględnione zostaną jedynie w stopniu niezbędnym do zreferowania tytułowego problemu. Bez wątpienia jednak kilku słów wprowadzenia wymaga tytułowa dla niniejszego artykułu tematyka komunikacji elektronicznej i to od niej rozpocząć należy ogół rozważań.

1 J. GoŁACZYŃsKi, Umowy elektroniczne w prawie prywatnym międzynarodowym, Warszawa 2007, s. 63. 
2. KomuniKaCja ELEKTRONiCZna I JEJ WPEYW NA POSTAĆ OŚWIADCZENIA WOLI

Punktem wyjścia do dalszych analiz uczynić należy podkreślenie faktu, że oświadczenie woli - bez względu na jego postać, formę, otoczenie technologiczne, czas i miejsce złożenia czy inne dotyczące go okoliczności - zawsze pozostaje tą samą instytucją prawa cywilnego. Jak podkreśla Zbigniew Radwański: „Oświadczenia woli składane w postaci elektronicznej - w tym także w sposób zautomatyzowany - są normalnymi oświadczeniami woli, nie różniącymi się co do swojej istoty od oświadczeń woli składanych w inny sposób (ustnie, pisemnie, w sposób dorozumiany). Inne założenie należałoby uznać za nieużyteczne ze względów pragmatycznych, ponieważ niesłychanie komplikowałoby obrót gospodarczy" ${ }^{2}$. Zapatrywaniu temu wtóruje Dariusz Szostek, zdaniem którego wszelkie zasady dotyczące „normalnego” oświadczenia woli mają także zastosowanie w stosunku do oświadczenia „elektronicznego"3.

Powyższe nie oznacza jednak, że specyfika komunikacji elektronicznej pozostaje bez wpływu na instytucję oświadczenia woli. Nie sposób bowiem nie dostrzec fundamentalnego oddziaływania, jakie rozwój technologii porozumiewania się wywarł na kształt ujmowania w nauce i stosowania w praktyce tejże instytucji prawa cywilnego. Wpływ ten odcisnął swoje piętno na wszystkich obszarach funkcjonowania oświadczenia woli i zmusił do zaktualizowania spojrzenia na wiele kwestii, które nie budziły wcześniej większych wątpliwości (jak np. wspomniany czas oraz miejsce złożenia czy podstawy przypisywalności oświadczenia woli) ${ }^{4}$. Rozwój nowych metod komunikacji zmusił również

\footnotetext{
Z. RADWAŃsKi, Teorie oświadczeń woli w świetle najnowszych zjawisk społecznych-komunikacji elektronicznej i ochrony konsumentów, [w:] Prawo prywatne czasu przemian. Księga pamiątkowa dedykowana Profesorowi Stanisławowi Sołtysinskiemu, red. A. Nowicka, Poznań 2005, s. 257.

D. Szostek, Czynność prawna a środki komunikacji elektronicznej, Kraków 2004, s. 41.

4 Por. szerzej Z. RadWAŃski, [w:] System prawa prywatnego. Prawo cywilne - część ogólna, II, red. Z. RADWAŃski, Warszawa 2008, nb 57, s. 21.
} 
do ponownego pochylenia się nad zagadnieniami podstawowymi, takimi jak istota pojęcia oświadczenia woli, okazało się bowiem, że wiele spośród dotychczasowych koncepcji nie było w stanie posłużyć do ujęcia w swoje ramy nowych technologii porozumiewania się. Wszystko to sprawiło, że nowoczesne metody komunikacji - ujęte w niniejszym artykule pod zbiorczym i celowo niedookreślonym terminem „komunikacji elektronicznej" - posłużyły za swoisty papierek lakmusowy dla dotychczasowej nauki prawa o oświadczeniu woli i zmusiły do aktualizacji spojrzenia na wszystkie niemal aspekty teoretyczne tego zagadnienia ${ }^{5}$.

Dobór wspomnianego zwrotu, a mianowicie komunikacji elektronicznej - jak już wspomniano - nie jest przypadkowy. Względem niektórych pojęć - zwłaszcza zaś terminów technicznych, nawiązujących do konkretnych rozwiązań technologicznych - wskazane jest zachowanie pewnej elastyczności oraz dystansu. Takie podejście wpisuje się w podnoszony w nauce prawa postulat zachowywania technologicznej neutralności, a zatem uwalniania określeń języka prawnego (a tym samym prawniczego) od terminów, które mogłyby krępować zakres zastosowania określonych norm prawnych oraz ich elastyczność ${ }^{6}$. Sprawa nabiera szczególnej doniosłości, gdy ustawodawca chętnie nawiązuje do określeń zaczerpniętych z języka nowych technologii komunikacyjnych, używając ich nawet w ogólnych przepisach prawa cywilnego, dokonując tym samym uwiązania wyrażonych w nich norm w siatkę pojęć

5 Por. szerzej Z. Radwański, Teorie..., s. 253. Problematyka ta jest oczywiście niezwykle obszerna i obejmuje wiele zagadnień związanych z całym instrumentarium jurydycznym (wraz z siatką pojęć, na których normy te są zbudowane) dotyczącym instytucji oświadczenia woli oraz czynności prawnej, w tym miejscu zaś została jedynie zasygnalizowana jako zjawisko o fundamentalnym wpływie na ten obszar nauki prawa cywilnego.

${ }^{6}$ Por. np. M. Maciejewska-SzaŁas, Forma pisemna i elektroniczna czynności prawnych. Studium prawnoporównawcze, Warszawa 2014, s. 1; M. MARUCHA-JAwORSKA, Podpisy elektroniczne, biometria, identyfikacja elektroniczna. Elektroniczny obrót prawny w społeczeństwie cyfrowym, Warszawa 2015, s. 81; D . Szostek, wykład pt. Dokument elektroniczny w świetle nowelizacji przepisów k.c. i k.p.c., http://notariat.pl/wiadomosci-notariat/353-dokument-elektroniczny-w-swietle-nowelizacji-przepisow-kc-i-kpc (dostęp 28 lutego 2020 r.). 
technicznych ${ }^{7}$. Termin komunikacji elektronicznej - w przeciwieństwie do takich określeń, jak chociażby „środek komunikacji elektronicznej” (np. art. $61 \S 2$ k.c.) czy nawet „postać elektroniczna” (np. art. 60, art. 66 art. $70 \$ 2$, art. $78^{1} \$ 1$ k.c.) - nie jest zaś co do zasady „normatywnie uwiązany", dzięki czemu jego użycie nie pociąga ze sobą konsekwencji cywilnoprawnych (często niepożądanych i niepotrzebnych) i w sposób elastyczny oraz pojemny może objąć swoim zakresem znaczeniowym ogół nowoczesnych metod porozumiewania się. Podkreślić należy przy tym, że określenie „oświadczeń woli składanych w toku komunikacji elektronicznej” odnosi się do wszelkich oświadczeń woli, które zostały złożone w postaci danych elektronicznych, te zaś rozumieć należy w sposób możliwie najszerszy ${ }^{8}$.

\section{Ustalanie PRAWA WŁAŚCIWEGO DLA CZYNNOŚCI PRAWNYCH DOKONANYCH W TOKU KOMUNIKACJI ELEKTRONICZNEJ}

\subsection{Uwagi ogólne}

U progu dalszych analiz wskazać należy, że mając na uwadze wzajemne powiązanie zagadnień oświadczenia woli oraz czynności prawnej, jak również brak wyraźnego wyodrębnienia pierwszego z tychże pojęć w ramach niektórych systemów prawnych, duża część dalszych rozważań będzie posługiwać się terminem czynności prawnej, nie zaś

Por. J. JANOwski, Elektroniczny obrót prawny, Warszawa 2008, s. 75; X. KoNARski, Komentarz do ustawy o świadczeniu usług droga elektroniczna, Warszawa 2004, s. 73-75; D. Кот, Zawarcie umowy za pomoca elektronicznych środków porozumiewania się na odległość (uwagi na tle projektowanych zmian kodeksu cywilnego), [w:] Zagadnienia prawa własności intelektualnej: Profesorowi Stefanowi Grzybowskiemu pracownicy Instytutu Wynalazczości i Ochrony Własności Intelektualnej w darze, red. J. SAdok, Kraków 2002, s. 59 i n.; D. Szostek, Czynność..., s. 34 i n.

8 Por. szerzej F. Wejman, Wprowadzenie do cywilistycznej problematyki ustawy o podpisie elektronicznym, «Prawo Bankowe» 2/2002, s. 37. Por. definicja terminu „elektroniczny” (electronic) w UETA (Uniform Electronic Transactions Act, akt prawa wzorcowego Stanów Zjednoczonych Ameryki, http://uniformlaws.org/ (dostęp 7 stycznia 2020 r.). 
oświadczenia woli, rzecz jasna przy pełnej świadomości odrębności desygnatów obydwu tych pojęć w polskim systemie prawnym. Trafnie tłumaczy tę sytuację Michał Wojewoda, wyjaśniając: „Terminologia kolizyjna nie zawsze pokrywa się z pojęciami i klasyfikacjami danego porządku krajowego. [...] Stąd też, niejako z definicji, język norm kolizyjnych musi być bardziej uniwersalny i elastyczny. Należy unikać zbyt ścisłego przywiązania do konkretnych rozwiązań materialnoprawnych przyjmowanych w prawie krajowym"9.

Punktem wyjścia do dalszych rozważań warto uczynić słowa Joanny Kuleszy, zdaniem której: „Jako że wszystkie treści internetowe mogą być odbierane na całym świecie, każdy użytkownik Internetu może potencjalnie stać się podmiotem każdej z jurysdykcji państwowych. [...] W tym kontekście prawie każde działanie podejmowane w Internecie posiada aspekt międzynarodowy, który może prowadzić do konfliktu jurysdykcyjnego"10. Stwierdzenie to jest rzecz jasna w pewnym stopniu oczywiste, pomaga jednak w dostrzeżeniu roli, jaką pełni przedmiotowa problematyka w ramach całego zagadnienia komunikacji elektronicznej. Z przywołanymi słowami korespondują dobrze uwagi Jacka Gołaczyńskiego, który trafnie podkreśla, że: „Postronny obserwator (internauta) może być skłonny przyjąć, iż Internet rządzi się własnymi prawami, a może nawet stoi poza porządkiem krajowym. Musimy jednak pamiętać, iż społeczeństwo informacyjne składa się z jednostek, które tak w sieci, jak w realnym świecie chcą być pewni swych praw i mieć poczucie bezpieczeństwa własnych interesów. Każda ze stron umowy oczekuje, że jej świadczenie będzie odwzajemnione przez drugą stronę w sposób oczekiwany i określony kontraktem" ${ }^{11}$. Zagadnienie ustalenia prawa właściwego dla czynności prawnej dokonanej w toku komunikacji elektronicznej jest zatem problematyką kluczową i w pewnym sensie pierwotną wobec wielu innych zagadnień związanych z szeroko rozumianym obrotem elektronicznym. Należy przy tym pamiętać, że specyfika komunikacji elektronicznej - pomimo doniosłości cech, które

9 M. WoJewoda, [w:] System prawa prywatnego. Prawo prywatne międzynarodowe, XX A, red. M. PAzDAN, Warszawa 2014, s. 738.

10 J. Kulesza, Międzynarodowe prawo Internetu, Poznań 2010, s. 179.

11 J. GoŁaCZyński, op. cit., s. 52. 
odróżniają ją od pozostałych kanałów komunikacji - nie pomniejsza roli tradycyjnych łączników używanych w międzynarodowym prawie prywatnym, choć oczywiście stawia przed podmiotem posługującym się nimi nowe wyzwania ${ }^{12}$.

Podejmując próbę zarysowania ogólnych ram poruszanego aspektu, poczynić można generalny wniosek, stosownie do którego prawo właściwe dla danej czynności prawnej może zostać albo wskazane przez jej strony (jeśli wybór prawa jest dla danej czynności prawnej dopuszczalny), albo też wyznaczone przez normy prawa prywatnego międzynarodowego (za pośrednictwem normy kolizyjnej posługującej się łącznikiem obiektywnym). Obowiązujące w Polsce regulacje z zakresu międzynarodowego prawa prywatnego - w obszarze relewantnym dla niniejszego artykułu - to przede wszystkim ustawa z 4 lutego 2011 r. Prawo prywatne międzynarodowe ${ }^{13}$, rozporządzenie Parlamentu Europejskiego i Rady nr 593/2008 z 17 czerwca 2008 r. w sprawie prawa właściwego dla zobowiązań umownych (tzw. Rzym I) ${ }^{14}$ oraz rozporządzenie Parlamentu Europejskiego i Rady nr 864/2007 z 11 lipca 2007 r. o prawie właściwym dla zobowiązań pozaumownych (tzw. Rzym II) ${ }^{15}$. Pamiętać należy również o zawartych przez Polskę konwencjach bilateralnych, zwłaszcza zaś tych, których drugą stroną nie jest państwo członkowskie Unii Europejskiej ${ }^{16}$.

12 Por. A.M. ZaChARIASIEWICZ, Zawarcie umowy w drodze elektronicznej a prawo prywatne międzynarodowe, [w:] Kolizyjne aspekty zobowiązań elektronicznych, red. J. GoŁACZYŃski, Warszawa 2008, s. 105.

13 Tekst jedn. Dz. U. z 2015 r. poz. 1792; dalej: p.p.m.

14 Dz. Urz. UE L 177 z 4 lipca 2008 r., s. 6-16. Rozporządzenie to zastąpiło obowiązującą w Polsce do 7 grudnia 2009 r. Konwencję o prawie właściwym dla zobowiązań umownych, otwartą do podpisu w Rzymie 19 czerwca 1980 r., zwaną konwencją rzymską z 1980 r.

15 Dz. Urz. UE L 199 z 31 lipca 2007 r., s. 40-49.

16 W myśl art. 25 ust. 2 rozporządzenia Rzym I przepisy rozporządzenia zachowują pierwszeństwo wobec konwencji bilateralnych i multilateralnych, których stronami są wyłącznie państwa członkowskie. 
3.2. Prawo właściwe dla dokonania oraz dopuszczalności czynności prawnej

Kwestią pierwotną wobec zagadnienia wyboru prawa właściwego, jak również wobec kwestii jego ustalania w razie braku tegoż wyboru, jest problematyka ustalania prawa właściwego dla dokonania oraz dopuszczalności czynności prawnej i to od niej należy rozpocząć rozważania niniejszej sekcji. Jak wskazuje M. Wojewoda, jednym z pierwszych zagadnień podlegających ocenie w ramach kolizyjnoprawnej analizy czynności prawnej jest problem jej dopuszczalności oraz pytanie o to, czy czynność rzeczywiście doszła do skutku, a zatem czy została dokonana ${ }^{17}$. Okoliczność prawa właściwego do stwierdzenia dopuszczalności (ważności materialnej) oraz dokonania czynności prawnej - w odniesieniu do umów obligacyjnych - unormowana została w art. 10 rozporządzenia Rzym I, stosownie do którego:

1. istnienie i ważność umowy lub jednego z jej postanowień ocenia się według prawa, które zgodnie z niniejszym rozporządzeniem byłoby dla niej właściwe, gdyby umowa lub jej postanowienie były ważne;

2. jeżeli jednak z okoliczności wynika, że nie byłoby uzasadnione dokonywanie oceny skutków zachowania się jednej ze stron według prawa określonego zgodnie $\mathrm{z}$ ust. 1 , strona ta może - w celu ustalenia, że nie wyraziła zgody na zawarcie umowy - powołać się na prawo państwa miejsca swojego zwykłego pobytu.

W przypadku czynności prawnych innych niż umowy obligacyjne (gdyż wobec tych ostatnich - w myśl zasady lex specialis derogat legi generali - zastosowanie znajduje przywołany art. 10 rozporządzenia Rzym I) obowiązuje natomiast art. 24 p.p.m., którego treść również oparta została na zasadniczej właściwości legis causae, czyli prawu właściwemu dla samej czynności. Stosownie do wspomnianego przepisu:

1. przy ustalaniu, czy dokonano czynności prawnej, stosuje się prawo dla niej właściwe;

2. strona, która twierdzi, że nie złożyła oświadczenia woli, może się powołać na prawo państwa, w którym ma miejsce zwykłego

17 M. WoJEWOdA, op. cit., s. 738. 
pobytu, jeżeli z okoliczności wynika, że ocena skutków jej zachowania według prawa wskazanego w przepisie ust. 1 nie byłaby zasadna.

Już na pierwszy rzut oka widać jednak, że przywołany przepis - odmiennie niż zacytowana uprzednio norma wspólnotowa - zajmuje się wyłącznie kwestią dokonania czynności prawnej, nie zaś zagadnieniem prawa właściwego dla ustalania ważności materialnej czynności. Chodzi tu o takie zagadnienia, jak między innymi kauzalność czynności, jej zgodność z prawem czy też problematyka wad oświadczeń woli ${ }^{18}$. Ponadto rozporządzenie dotyczy wyłącznie umów, podczas gdy przepis polskiej ustawy obejmuje także problem dokonywania czynności prawnych jednostronnych. Abstrahując od powyższych odmienności, obydwa uregulowania - posiłkując się słowami M. Wojewody - stanowią w zasadzie o tym samym, choć przy użyciu różnych zwrotów ${ }^{19}$. W obydwu przypadkach proces poszukiwania prawa właściwego dla kwestii dokonania czynności prawnej opiera się na mechanizmie, w ramach którego identyfikacja legis causae wymaga tymczasowego przyjęcia, że czynność została skutecznie dokonana i że jest czynnością danego typu, a następnie posłużenia się odpowiednią regułą kolizyjną, pozwalającą ustalić statut danej czynności ${ }^{20}$.

\subsection{Wybór prawa}

Swoboda wyboru prawa jest uznawana za jedną z podstawowych wolności jednostki i jako taka uwzględniona została w wielu konwencjach oraz rezolucjach ONZ ${ }^{21}$. Źródła prawa międzynarodowego prywatnego wyrażają to uprawnienie na różne sposoby oraz w zróżnicowanym zakresie. Stosownie do art. 4 ust. 1 p.p.m.: „W przypadkach przewidzianych w ustawie można dokonać wyboru prawa właściwego”. Jako przykład takiego przypadku wskazać można art. 38 ust. 1 ustawy, zgodnie z którym

18 Kwestie te również podlegają właściwości legis causae, ale wykraczają poza pojęcie dokonania czynności i jako takie nie zostały objęte komentowaną regulacją. Por. M. Wojewoda, op. cit., s. 745.

19 Ibidem, s. 742.

20 Ibidem.

${ }^{21}$ J. GoŁaCZyŃsKi, op. cit., s. 90. 
umowa o arbitraż podlega prawu wybranemu dla niej przez strony. W rozporządzeniu Rzym I swobodę wyboru prawa wyraża natomiast art. 3. Stosownie do art. 3 ust. 1: „Umowa podlega prawu wybranemu przez strony. Wybór prawa jest dokonany wyraźnie lub w sposób jednoznaczny wynika z postanowień umowy lub okoliczności sprawy. Strony mogą dokonać wyboru prawa właściwego dla całej umowy lub tylko dla jej części”.

Istota wyboru prawa wymaga kilku słów komentarza. Po pierwsze, stanowi on odrębną od umowy materialnej czynność prawną, która może zostać dokonana przed kontraktem głównym, wraz z nim (jako jedna z jego klauzul), jak również po jego zawarciu. Rodzi to wiele konsekwencji, jak chociażby tę, że wybór taki może zostać dokonany również w sposób dorozumiany (poprzez konkludentne oświadczenia woli). Po drugie, wybór ten może stanowić bezpośrednie wskazanie danego systemu prawnego, ale może też sprowadzać się tylko do podania łącznika wskazującego właściwe prawo. Po trzecie, wykluczony jest wybór negatywny, który miałby na celu jedynie uchylenie właściwego prawa przewidzianego normą kolizyjną i przez to doprowadzenie do sytuacji, w której czynność prawna nie podlega żadnemu prawu - taki „wybór” nie stanowi wyboru prawa i nie spełnia funkcji łącznika. Po czwarte, przedmiotem wyboru musi być obowiązujący na danym terytorium porządek prawny. Oznacza to, po pierwsze, że może zostać wybrane również prawo prowincjonalne w kraju o niejednolitym systemie, ma to jednak również i tę konsekwencję, iż wybór dotyczy całego porządku prawnego, a zatem na przykład obok przepisów prawa cywilnego zastosowanie mogą znaleźć również bezwzględnie obowiązujące regulacje należące do innych dziedzin prawa. Wybór odnosi się jednak wyłącznie do norm prawa materialnego, w dodatku nie wszystkich, ponieważ nie obejmuje norm kolizyjnych prawa prywatnego międzynarodowego. Należy ponadto pamiętać, że dopuszczalność wyboru odnosi się wyłącznie do zobowiązań z elementem zagranicznym, o czym decydują elementy obiektywne (np. miejsce zamieszkania, obywatelstwo, miejsca 
zawarcia lub wykonania umowy) ${ }^{22}$. Stosownie do art. 1 ust. 1 rozporządzenia Rzym I: „Niniejsze rozporządzenie stosuje się do zobowiązań umownych w sprawach cywilnych i handlowych powiązanych $\mathrm{z}$ prawem różnych państw”. Polska ustawa statuuje swój przedmiot i zakres w równie ogólnym stopniu. Artykuł 1 p.p.m. stanowi: „Ustawa niniejsza reguluje właściwość prawa dla stosunków z zakresu prawa prywatnego związanych z więcej niż jednym państwem”. Ponadto - jak już wspomniano - regulacje wyrażające swobodę wyboru prawa mogą zawierać rozmaite ograniczenia, wynikające między innymi z natury danego stosunku (np. umowy konsumenckie) czy z klauzuli porządku publicznego (np. art. 7 p.p.m.) $)^{23}$.

Jeśli chodzi o problematykę wyboru prawa w przypadku czynności prawnych dokonywanych w toku komunikacji elektronicznej, rozważyć należy kilka kwestii. Przede wszystkim uwagi wymaga zasygnalizowany uprzednio wymóg „międzynarodowego charakteru” danej czynności, który stanowi warunek dopuszczalności wyboru prawa. Jak podkreśla Wojciech Popiołek: „[...] w uproszczeniu wymóg ten oznacza, że chodzi o taką umowę, która powiązana jest (wykazuje związki) z obszarem więcej niż jednego państwa, przy czym współcześnie za wystarczające uznaje się, by były to związki jakiegokolwiek rodzaju [...]”24. Fundamentalne pytanie, jakie nasuwa się w tym miejscu, dotyczy mechanizmu kwalifikacji czynności prawnej dokonanej w ramach komunikacji elektronicznej jako posiadającej ów „międzynarodowy charakter”. Kwestia ta jest kluczowa - zważywszy na jej rozstrzygającą rolę w możliwości dokonania wyboru prawa - a jednocześnie skomplikowana, wziąwszy pod uwagę specyfikę komunikacji elektronicznej, która korzysta z sieci, połączeń, urządzeń oraz mechanizmów rozlokowanych niemal po całym świecie, a w ramach której impulsy elektroniczne w ciągu jednej chwili

22 Tak J. Go£Aczyński, op. cit., s. 104; odmiennie: W. PopioŁek, Prawo właściwe dla umownych zobowiązań elektronicznych $w$ konwencji rzymskiej i projekcie rozporzadzenia Rzym I, [w:] Kolizyjne aspekty zobowiązań elektronicznych. Materiały z konferencji, red. J. GoŁACZyński, Warszawa 2008, s. 16.

23 J. GoŁACZYŃski, op. cit., s. 102-106. Przypis dotyczy ogółu rozważań niniejszego akapitu.

24 W. PopioŁek, op. cit., s. 12. 
„przemieszczają” się o tysiące kilometrów. Z uwagi na powyższe z jednej strony można argumentować, że immanentną cechą każdej czynności prawnej dokonanej w toku komunikacji elektronicznej jest „przymiot międzynarodowości”"25. Z drugiej jednak podnosić można, że specyfika funkcjonowania komunikacji elektronicznej ma charakter nie tyle międzynarodowy, ile raczej ponadnarodowy, zaś globalne sieci (np. Internet) są niejako „pozaprzestrzenne”, dlatego okoliczność „przemieszczania się impulsu elektrycznego" po całym świecie ma w tym kontekście obojętny charakter ${ }^{26}$. Wydaje się, że należy przychylić się do drugiego ze wskazanych poglądów. Okoliczność skomplikowanego charakteru technicznych uwarunkowań komunikacji elektronicznej, zwłaszcza zaś problematyka lokalizacji i przemieszczania się impulsu elektrycznego, jest sama w sobie neutralna i niejako „przezroczysta”. Uznanie tej okoliczności - w oderwaniu od pozostałych aspektów dotyczących danej czynności - za spełniającą przesłankę związku z obszarem więcej niż jednego państwa, zdawałoby się pewnym nadużyciem, które spychałoby na dalszy plan lub wręcz pomijało rzeczywiste i relewantne dla istoty czynności prawnej oraz dla jej stron powiązania, takie jak na przykład miejsce zwyczajnego pobytu, miejsce zamieszkania, miejsce siedziby lub prowadzenia przedsiębiorstwa czy też miejsce, w którym mają powstać skutki umowy. Trafnie podkreśla więc W. Popiołek, wskazując, że w świetle powyższego znaczenie okazują się mieć nadal powiązania „klasyczne”27. Jeśli więc wszystkie elementy stanu faktycznego związanego z daną czynnością prawną są zlokalizowane w ramach porządku prawnego jednego państwa, to czynność ta nie może zostać uznana za „powiązaną z prawem różnych państw” jedynie na podstawie tego, że została dokonana w toku komunikacji elektronicznej. Okoliczność ta jako taka jest w tym przypadku neutralna. W tym miejscu należy jednak podkreślić, że rozważania te abstrahują od kwestii korzystania z usług

25 Na takim stanowisku - choć z pewnymi zastrzeżeniami - zdaje się stać niemiecki autor P. Mankowski, Das Internet im Internationalen Vertrags- und Deliktsrecht, «Rabels Zeitschrift für ausländisches und internationales Privatrecht» 2/1999, s. 208, 209.

26 Zwolennikiem tego stanowiska jest W. PopıoŁek, op. cit., s. 12, 13.

27 Ibidem, s. 13. 
serwerów (wówczas ich lokalizacja może mieć wpływ na aspekt „międzynarodowości” takich czynności prawnych), zaś celem powyższych dywagacji jest jedynie ukazanie, iż okoliczność posłużenia się przy dokonywaniu czynności prawnej określonym środkiem komunikacji sama przez się nie decyduje o przyznaniu takiej czynności „przymiotu międzynarodowości”.

Należy w tym miejscu zauważyć, że zdecydowana większość czynności prawnych dokonywanych w toku komunikacji elektronicznej to umowy obligacyjne w sprawach cywilnych i handlowych. W związku z powyższym - oceniając sprawę z perspektywy polskiego prawa zastosowanie względem nich znajduje co do zasady rozporządzenie Rzym I (art. 1 ust. 1 rozporządzenia Rzym I w zw. z art. 28 ust. 1 p.p.m.). $\mathrm{Z}$ tego względu akt ten stanowić winien główny przedmiot analizy bieżących rozważań, co niniejszym - w odniesieniu do kwestii wyboru prawa właściwego - a następnie - w stosunku do zagadnienia prawa właściwego w braku wyboru prawa - zostanie uczynione. Rozporządzenie Rzym I, które zastąpiło konwencję rzymską, utrzymało podstawowe jej założenia i większość rozwiązań szczegółowych. Pomimo faktu, że $\mathrm{w}$ trakcie dyskusji nad projektem rozporządzenia rozważano również kwestie związane z umowami zawartymi w toku komunikacji elektronicznej ${ }^{28}$, ostatecznie nie zdecydowano się na szczegółowe uregulowanie tej problematyki. Z tego względu w dalszym ciągu przedmiotem analizy w kwestii wyboru prawa właściwego dla umów obligacyjnych zawartych w ramach komunikacji elektronicznej są ogólne zasady kolizyjne. Wszelkie poczynione dotychczas w tym zakresie rozważania - w szczególności zaś przywoływany już art. 3 ust. 1 rozporządzenia przyznający pierwszoplanowe miejsce łącznikowi wyboru prawa, jak również dywagacje poświęcone „międzynarodowemu charakterowi” czynności prawnej dokonanej w ramach komunikacji elektronicznej - pozostają w tym miejscu aktualne. Skoro zatem co do zasady brak jest odrębności w zakresie zagadnienia wyboru prawa pomiędzy umowami „klasycznymi” a tymi zawieranymi w toku komunikacji elektronicznej, dalszą analizę tej kwestii w niniejszym artykule uznać należy za bezprzedmiotową.

28 Ibidem, s. 22, 23. 


\subsection{Prawo właściwe w braku wyboru prawa}

W pozostałych przypadkach, tj. w sytuacji niedopuszczalności wyboru prawa lub w przypadku braku dokonania takiego wyboru, prawo właściwe ustalane jest na podstawie norm kolizyjnych prawa międzynarodowego prywatnego, w oparciu o przewidziane przez nie łączniki.

Na wstępie podkreślić należy, że również w tym wypadku zastosowanie obydwu analizowanych aktów prawa międzynarodowego prywatnego (rozporządzenie Rzym I oraz prawo prywatne międzynarodowe) zależy od posiadania przez daną czynność prawną analizowanego już „przymiotu międzynarodowości”. Rozważania dokonane uprzednio w tym zakresie zachowują więc wobec bieżącej problematyki swoją aktualność i jako takie nie będą w tym miejscu powtarzane.

W dalszej kolejności przejść należy do analizy treści art. 4 rozporządzenia Rzym I, stosownie do którego:

1. W zakresie, w jakim nie dokonano wyboru prawa właściwego dla umowy zgodnie $\mathrm{z}$ art. $3 \mathrm{i}$ bez uszczerbku dla art. 5-8, prawo właściwe dla umowy ustala się następująco:

a. umowa sprzedaży towarów podlega prawu państwa, w którym sprzedawca ma miejsce zwykłego pobytu;

b. umowa o świadczenie usług podlega prawu państwa, w którym usługodawca ma miejsce zwykłego pobytu;

c. umowa, której przedmiotem jest prawo rzeczowe na nieruchomości lub prawo do korzystania z nieruchomości, podlega prawu państwa, w którym nieruchomość jest położona;

d. niezależnie od lit. c), umowa dotycząca czasowego korzystania z nieruchomości na użytek własny, zawarta na okres nie dłuższy niż sześć kolejnych miesięcy, podlega prawu państwa, w którym oddający nieruchomość do korzystania ma miejsce zwykłego pobytu, pod warunkiem że biorący do korzystania jest osobą fizyczną i ma miejsce zwykłego pobytu w tym samym państwie;

e. umowa franczyzy podlega prawu państwa, w którym franczyzobiorca ma miejsce zwykłego pobytu;

f. umowa dystrybucji podlega prawu państwa, w którym dystrybutor ma miejsce zwykłego pobytu; 
g. umowa sprzedaży towarów w drodze licytacji podlega prawu państwa, w którym odbywa się licytacja, jeżeli miejsce to można ustalić;

h. umowa zawarta w ramach wielostronnego systemu, który kojarzy lub ułatwia kojarzenie wielu transakcji kupna i sprzedaży instrumentów finansowych w rozumieniu definicji z art. 4 ust. 1 pkt 17 dyrektywy 2004/39/WE, zgodnie z regułami innymi niż uznaniowe, i który podlega jednemu prawu, podlega temu właśnie prawu.

2. Umowa, która nie jest objęta ust. 1 lub której składniki byłyby objęte zakresem więcej niż jednego z przypadków określonych w ust. 1 lit. a-h, podlega prawu państwa, w którym strona zobowiązana do spełnienia świadczenia charakterystycznego dla umowy ma miejsce zwykłego pobytu.

3. Jeżeli ze wszystkich okoliczności sprawy wyraźnie wynika, że umowa pozostaje w znacznie ściślejszym związku z państwem innym niż państwo wskazane w ust. 1 lub 2, stosuje się prawo tego innego państwa.

4. Jeżeli nie można ustalić prawa właściwego zgodnie z ust. 1 lub 2, umowa podlega prawu państwa, z którym wykazuje najściślejszy związek.

Rozporządzenie wprowadza wiele powiązań, które mają „sztywny” charakter w tym znaczeniu, że nie stanowią domniemań ani nie mogą być co do zasady zastąpione powiązaniem $\mathrm{z}$ innym państwem na podstawie ogólnej klauzuli „wymijającej” odnoszącej się do „ściślejszych związków”, jak to miało miejsce w konwencji rzymskiej ${ }^{29}$. Należy jednak zwrócić uwagę na ust. 3, który - choć obarczony relatywnie trudnymi do spełnienia przesłankami (związek z innym państwem musi być znacznie ściślejszy i musi wynikać ze wszystkich okoliczności sprawy) - wyraża klauzulę nakazującą stosowanie prawa innego państwa niż wskazane w ust. 1 lub 2. Co jednak najistotniejsze z punktu widzenia niniejszego artykułu, przepis ten nie wprowadza rozwiązań problematycznych dla czynności prawnych (a w zasadzie dla umów, mowa bowiem o zakresie

29 Ibidem, s. 25. 
zastosowania rozporządzenia Rzym I) dokonywanych w ramach komunikacji elektronicznej ani nie prowadzi w tym zakresie do żadnych odmienności względem czynności tradycyjnych. Należy bowiem pamiętać, że miejsce zwykłego pobytu - łącznik, do którego szeroko odwołuje się art. 4 rozporządzenia - nie odpowiada miejscu przebywania danej osoby w momencie zawarcia umowy (co byłoby problematyczne w przypadku umów zawieranych drogą elektroniczną), lecz ustalane jest w oparciu o kryteria znacznie bardziej „stabilne”, takie jak na przykład miejsce głównego przedsiębiorstwa (w przypadku osoby fizycznej, działającej w ramach prowadzonej przez nią działalności gospodarczej) $)^{30}$. Wprawdzie chwilą relewantną dla okoliczności ustalania miejsca zwykłego pobytu jest moment zawarcia umowy (art. 19 ust. 3 rozporządzenia Rzym I), co tak czy inaczej prowadzić może do konieczności analizy kwestii chwili złożenia oświadczenia woli w toku komunikacji elektronicznej oraz zawarcia umowy opartej na takich oświadczeniach, z uwagi jednak na małą zmienność miejsca zwykłego pobytu nie prowadzi to do większych trudności. Do funkcjonowania zasady państwa pochodzenia - bo to ją wprowadza analizowany łącznik - względem czynności prawych dokonywanych w toku komunikacji elektronicznej, nawiązuje również treść dyrektywy nr 2000/31/WE o handlu elektronicznym ${ }^{31}$. W zakresie relewantnym z punktu widzenia niniejszych rozważań wspomnienia wymaga zwłaszcza pkt 19 preambuły tejże dyrektywy, stosownie do którego: „Miejsce siedziby usługodawcy powinno być ustalone zgodnie z orzecznictwem Trybunału Sprawiedliwości, zgodnie z którym pojęcie siedziby mieści w sobie faktyczne prowadzenie działalności gospodarczej [...] miejscem siedziby przedsiębiorstwa świadczącego usługi za pośrednictwem internetowej witryny

\footnotetext{
30 Art. 19 ust. 1 rozporządzenia Rzym I.

31 Dyrektywa 2000/31/WE Parlamentu Europejskiego i Rady z 8 czerwca 2000 r. w sprawie niektórych aspektów prawnych usług społeczeństwa informacyjnego, w szczególności handlu elektronicznego w ramach rynku wewnętrznego (Dz. Urz. WE L 178 z 17 lipca 2000 r., s. 1-16). Dyrektywa statuuje tę zasadę w celu określenia prawa merytorycznego właściwego dla oceny stosunku prawnego wynikającego z umowy o świadczenie usług społeczeństwa informacyjnego (art. 3); szerzej J. GoŁACzyńsKI, op. cit., s. 121; D. LuBAsz, Handel elektroniczny. Bariery prawne, Warszawa 2013, s. 116.
} 
www nie jest miejsce, gdzie znajdują się środki techniczne obsługujące jego witrynę www ani miejsce, z którego witryna www jest dostępna, lecz miejsce, gdzie wykonuje on swoją działalność gospodarczą [...]”. Powyższe uwagi - doniosłe dla problematyki funkcjonowania zasady państwa pochodzenia względem co najmniej niektórych umów zawieranych w toku komunikacji elektronicznej - uzupełnia trafny wniosek J. Gołaczyńskiego, zdaniem którego z perspektywy prawa prywatnego międzynarodowego nie można wnioskować o siedzibie przedsiębiorcy z nazwy domeny internetowej ${ }^{32}$. Obserwacje te potwierdza art. 6 ust. 5 konwencji ONZ z 2005 r. o zastosowaniu elektronicznej komunikacji w zawieraniu umów międzynarodowych, o której będzie jeszcze w niniejszym artykule mowa.

Ciekawszy z punktu widzenia komunikacji elektronicznej może okazać się natomiast art. 6 rozporządzenia Rzym I, odnoszący się do umów konsumenckich. Stosownie do art. 6 ust. 1 :

1. Bez uszczerbku dla art. 5 i 7 umowa zawarta przez osobę fizyczną w celu, który można uznać za niezwiązany z jej działalnością gospodarczą lub zawodową („konsument”), z inną osobą wykonującą działalność gospodarczą lub zawodową („przedsiębiorca”) podlega prawu państwa, w którym konsument ma miejsce zwykłego pobytu, pod warunkiem że przedsiębiorca:

a. wykonuje swoją działalność gospodarczą lub zawodową w państwie, w którym konsument ma miejsce zwykłego pobytu; lub

b. w jakikolwiek sposób kieruje taką działalność do tego państwa lub do kilku państw z tym państwem włącznie; a umowa wchodzi w zakres tej działalności.

W tym przypadku aspektem szczególnie interesującym z punktu widzenia tematu niniejszego artykułu jest przesłanka „,kierowania działalności do danego państwa”. Artykuł 6 ust. 1 lit. b wskazuje, że chodzi o „jakikolwiek sposób” kierowania, co oznacza, iż tyczy się to również kierowania za pośrednictwem komunikacji elektronicznej, w tym poprzez strony internetowe, które oferują zawarcie umowy w drodze

32 J. GoŁACZYŃski, op. cit., s. 99. 
elektronicznej ${ }^{33}$. Pozostając w obszarze wzajemnej korelacji zagadnień prawa prywatnego międzynarodowego oraz regulacji konsumenckich (na styku których funkcjonuje powszechnie komunikacja elektroniczna), warto wskazać również na treść art. 6 ust. 2 analizowanego rozporządzenia. Stosownie do tego przepisu: „Niezależnie od ust. 1, dla umowy, która spełnia warunki wymienione w ust. 1, strony mogą dokonać wyboru prawa właściwego zgodnie z art. 3. Wybór taki nie może jednak prowadzić do pozbawienia konsumenta ochrony przyznanej mu na podstawie przepisów, których nie można wyłączyć w drodze umowy, na mocy prawa, jakie zgodnie z ust. 1 byłoby właściwe w braku wyboru”. Warto pamiętać zatem, że wybór prawa właściwego decyzją stron doznaje w tym zakresie ograniczenia, którego celem jest ochrona słabszej ze stron stosunku prawnego.

Przepisem wymagającym wspomnienia z perspektywy komunikacji elektronicznej jest również art. 11 analizowanego rozporządzenia, który odwołuje się do miejsca przebywania stron w chwili zawarcia umowy. Przykładowo ust. 2 tego przepisu stanowi: „Umowa zawarta między osobami, które - lub których przedstawiciele - znajdują się w różnych państwach w chwili jej zawarcia, jest ważna ze względu na formę, jeżeli spełnia wymagania co do formy określone przez prawo właściwe dla umowy zgodnie z niniejszym rozporządzeniem lub prawo państwa, w którym w chwili zawarcia umowy znajduje się którakolwiek ze stron lub jej przedstawiciel, lub prawo państwa, w którym którakolwiek ze stron miała w tym czasie miejsce zwykłego pobytu”. Abstrahując od problematyki wpływu komunikacji elektronicznej na zagadnienie formy czynności prawnej, zauważyć należy, że przytoczony przepis jest $z$ punktu widzenia omawianej problematyki bardzo interesujący. W odróżnieniu od dotychczas przywoływanych norm rozporządzenia Rzym I posługuje się on bowiem pojęciami w pewnym stopniu „newralgicznymi” dla zagadnienia komunikacji elektronicznej. Relewantne nie jest w tym wypadku miejsce stałego pobytu, lecz ustalane każdorazowo w chwili zawarcia umowy (która to chwila sama w sobie jest już w przypadku komunikacji elektronicznej problematyczna) miejsce

33 Por. szerzej W. PopioŁek, op. cit., s. 25, 26. 
przebywania stron. Wszystko to powoduje, że stosowanie rozpatrywanego art. 11 w niektórych stanach faktycznych może okazać się zabiegiem dość utrudnionym. Pierwszy problem wynika ze skomplikowanego mechanizmu ustalania momentu zawarcia umowy opartej na oświadczeniach woli złożonych w toku komunikacji elektronicznej, drugi zaś związany jest z procedurą wskazywania miejsca przebywania stron umowy w tejże chwili, co w dobie globalizacji, nowoczesnych środków przemieszczania się oraz komunikacji elektronicznej może prowadzić do wielu problemów. Aspektom tym należy poświęcić w tym miejscu kilka uwag, gdyż - choć oba są zagadnieniami na tyle obszernymi, że ich wyczerpującemu omówieniu należałoby poświęcić osobne opracowanie - świadomość ogólnego zarysu ich specyfiki pozwala na lepsze zrozumienie problematyki kolizyjnej.

Zagadnienie chwili złożenia oświadczenia woli jest istotne nie tylko z uwagi na techniczne uwarunkowania komunikacji elektronicznej, lecz także ze względu na swoją praktyczną doniosłość. Warto przedstawić w tym miejscu zarys tejże problematyki, osadzając ją w ramach polskiego systemu prawnego. Czynności prawne podzielić można na wymagające dla swej skuteczności złożenia oświadczenia woli innemu podmiotowi oraz na takie, które do wywołania skutków prawnych nie potrzebują złożenia ich innej osobie. Czynności prawne oparte na oświadczeniach woli składanych w toku komunikacji elektronicznej stanowią w większości przypadków pierwszy spośród wymienionych rodzajów ${ }^{34}$. Z tego względu niezbędne jest ustalenie sposobu wyznaczania chwili złożenia oświadczenia woli innej osobie jako momentu, w którym rozpoczyna ono swój byt prawny i wywiera skutki prawne, ze wszystkimi tego konsekwencjami. Stosownie do art. $61 \$ 2$ k.c. oświadczenie woli wyrażone w postaci elektronicznej jest złożone innej osobie z chwilą, gdy wprowadzono je do środka komunikacji elektronicznej w taki sposób, żeby osoba ta mogła zapoznać się z jego treścią ${ }^{35}$. Pomijając w tym miejscu ewentualne zastrzeżenia co do konstrukcji tego przepisu (który stanowi

\footnotetext{
34 D. Szostek, Czynność..., s. 61.

35 Przepis ten jest transpozycją art. 11 dyrektywy 2000/31/WE o handlu elektronicznym.
} 
jeden z przykładów wspomnianego uprzednio „normatywnego uwiązania” terminu zaczerpniętego z języka elektronicznych technologii porozumiewania się), stwierdzić trzeba, że nawiązuje on do przyjętej w art. $61 \$ 1$ k.c. teorii doręczenia ${ }^{36}$. Należy wskazać, że przepis art. 61 $\$ 2$ k.c. nie wprowadza żadnej odmienności w stosunku do regulacji wyrażonej w art. $61 \$ 1$ k.c., stanowiąc w istocie - jak podnosi Jacek Janowski - „niepotrzebne jego powtórzenie” ${ }^{37}$. Różnica sprowadza się do zastąpienia terminu „dojście” sformułowaniem „wprowadzenie”, a jej istnienie wynika jedynie - jak wskazuje Dariusz Szostek - ze specyfiki środków komunikacji elektronicznej i reguł języka polskiego ${ }^{38}$. Zauważenia wymaga przy tym fakt, że moment „wprowadzenia do środka komunikacji elektronicznej” nie określa jeszcze chwili złożenia oświadczenia woli, ponieważ stosownie do analizowanego unormowania niezbędne jest takie wprowadzenie, które umożliwia adresatowi oświadczenia zapoznanie się z jego treścią. Wymóg ten otwiera pole do dalszych rozważań - tym szerszych, im bardziej zaawansowany (lub raczej „nietypowy”) jest dany środek komunikacji elektronicznej. Analizy wymaga przy tym wiele kwestii, jak chociażby istota niedookreślonego „wprowadzenia oświadczenia do środka komunikacji elektronicznej”, na gruncie tak ogólnego sformułowania nie wiadomo bowiem, czy wprowadzenie to następuje w chwili przejścia wiadomości przez interfejs systemu informatycznego serwera dostępnego odbiorcy, czy może później, na którymkolwiek z dalszych etapów „wirtualnej wędrówki” wiadomości przez serwery i łącza ${ }^{39}$. Zasadniczo więc przesłanka ta mimo że niezwykle doniosła $z$ uwagi na rolę, jaką pełni w procesie ustalania istoty elektronicznej postaci oświadczenia woli, łącząc to pojęcie z zagadnieniem środków komunikacji elektronicznej - nie pomaga przy analizie kwestii momentu złożenia oświadczenia woli, który ustalać trzeba niemal wyłącznie w oparciu o drugą użytą przez ustawodawcę przesłankę, dotyczącą możliwości zapoznania się z treścią oświadczenia

\footnotetext{
36 Z. Radwański, [w:] System..., s. 290, 291.

37 J. JANOWSKI, op. cit., s. 326.

38 D. Szostek, Czynność..., s. 62.

39 Por. szerzej J. Janowski, op. cit., s. 333. Por. postanowienie SN z 10 grudnia 2003 r., V CZ 127/03, «OSNC» 1/2005, poz. 12, s. 71.
} 
woli wprowadzonego do środka komunikacji elektronicznej. Również na gruncie tejże przesłanki sprawa przestawia się w sposób skomplikowany. Po pierwsze, badając konkretną sytuację pod kątem spełnienia przedmiotowej przesłanki, należy wyjść od ustalenia, czy w danym przypadku mamy do czynienia $\mathrm{z}$ komunikacją w obecności stron (inter presentes), czy też pomiędzy nieobecnymi (inter absentes), co samo w sobie jest już dość problematyczne ${ }^{40}$. Jeśli analiza danego przypadku każe uznać, że mamy do czynienia z komunikacją inter absentes, wówczas moment złożenia oświadczenia woli nie nastąpi w chwili wprowadzenia wiadomości do środka komunikacji elektronicznej, lecz później - gdy jego adresat będzie mógł zapoznać się z treścią oświadczenia (art. $61 \S 2$ k.c.). Literalne brzmienie analizowanej regulacji nie udziela przy tym odpowiedzi na pytanie o charakter owej możliwości, należy więc zastanowić się, jakie okoliczności nakazują uznać, że adresat oświadczenia woli winien zostać „obciążony” spełnieniem tej przesłanki. Nastręcza to dalszych trudności, nie ulega bowiem wątpliwości, że nie o rzeczywistą (tzn. indywidualnie, subiektywnie rozpatrywaną) możliwość tutaj chodzi, gdyż takie ujęcie zagrażałoby bezpieczeństwu obrotu, lecz o możliwość wyznaczoną miernikami obiektywnymi. Wspomniane trudności to oczywiście jedynie przykłady, potencjalnych problemów jest bowiem więcej ${ }^{41}$, wszystkie zaś czynią z procesu ustalania chwili złożenia oświadczenia woli w toku komunikacji elektronicznej (na kanwie obowiązującego systemu prawnego) przedsięwzięcie relatywnie skomplikowane.

Rozważania na temat momentu złożenia oświadczenia woli w toku komunikacji elektronicznej są rzecz jasna bezpośrednio powiązane z problematyką chwili zawarcia umowy w ramach tejże komunikacji. Stosownie do art. $70 \$ 1$ k.c. w razie wątpliwości umowę poczytuje się za zawartą w chwili otrzymania przez składającego ofertę oświadczenia o jej przyjęciu, a jeżeli dojście do składającego ofertę oświadczenia o jej

40 Zob. szerzej J. Janowski, op. cit., s. 328; D. Szostek, Czynność..., s. 63.

41 Jak chociażby kwestia rozkładu ryzyka pomiędzy nadawcą a adresatem wiadomości, trudności związane z art. 62 k.c., zagadnienie oświadczeń składanych ad incertas personas czy wreszcie problematyka oświadczeń woli generowanych w sposób zautomatyzowany. 
przyjęciu nie jest wymagane - w chwili przystąpienia przez drugą stronę do wykonania umowy. Odnosząc treść tego unormowania do dokonanych uprzednio rozważań, stwierdzić należy, że na ich tle kluczową rolę odgrywa pojęcie „otrzymania” oświadczenia woli, które rozumieć należy jako doręczenie, a więc - normatywnie rzecz ujmując - złożenie oświadczenia woli. Chodzi bowiem o ustalenie momentu, w którym oświadczenie woli będące odpowiedzią na ofertę zostaje złożone - a zatem powstaje jako byt prawny, wywołując skutek w postaci zawarcia umowy - nie zaś o ustalenie chwili faktycznego zapoznania się adresata z treścią oświadczenia, ten bowiem jest w świetle niniejszych rozważań co do zasady irrelewantny. Konstatacja ta stanowi naturalną konsekwencję przyjęcia przez polskiego ustawodawcę teorii doręczenia jako zasady określającej moment miarodajny dla chwili złożenia oświadczenia woli.

Druga wspomniana trudność związana ze stosowaniem art. 11 rozporządzenia Rzym I (i w ogóle z zagadnieniem ustalania chwili oraz miejsca dokonania czynności prawnej w toku komunikacji elektronicznej) związana jest z procedurą wskazywania miejsca przebywania stron umowy w chwili jej zawarcia ${ }^{42}$. Po pierwsze - co oczywiste - w pierwszej kolejności ustalenia wymaga chwila zawarcia takiej umowy, co - jak pokazano powyżej - samo w sobie nastręczać może wiele trudności. Należy zauważyć jednak, że nawet precyzyjne i niebudzące wątpliwości ustalenie chwili złożenia oświadczenia woli w toku komunikacji elektronicznej mogłoby nie gwarantować możliwości ustalenia dokładnego miejsca przebywania adresata w tak określonym momencie. Nietrudno wyobrazić sobie na przykład problem znajdującego się w podróży adresata oświadczenia woli, który stanąłby jakiś czas później przed koniecznością ustalenia precyzyjnego miejsca swojego pobytu w danej chwili, nawet jeśli ta wskazana zostałaby co do sekundy.

Poczynione powyżej wnioski pozwalają powrócić do analizy art. 11 rozporządzenia Rzym I. Czynnikiem w pewnym stopniu łagodzącym zarysowane trudności związane z ustalaniem miejsca i czasu złożenia

42 Czego nie należy mylić z miejscem zawarcia umowy, stanowi to bowiem zagadnienie odrębne, choć powiązane i również skutkujące wieloma interesującymi problemami natury prawnej. 
oświadczenia woli są dodatkowe łączniki wskazane w zacytowanej regulacji, które mogą w określonych sytuacjach przyjść z pomocą podmiotowi stosującemu przedmiotową normę. Przykładowo w razie braku możliwości ustalenia miejsca przebywania stron w chwili zawarcia umowy analizowany przepis wskazuje na prawo państwa, w którym którakolwiek ze stron miała w tym czasie miejsce zwykłego pobytu. Wspomniane hipotetyczne trudności mogą więc w praktyce występować relatywnie rzadko.

Na marginesie rozważań omawianej problematyki wspomnieć należy również o unormowaniach konwencji ONZ z 2005 r. o zastosowaniu elektronicznej komunikacji w zawieraniu umów międzynarodowych, stanowiącej uzupełnienie wcześniejszych instrumentów prawnych UNCITRAL (prawa modelowego o handlu elektronicznym z 1996 r. oraz prawa modelowego o podpisach elektronicznych z 2001 r. $)^{43}$. Akt ten merytorycznie oparty na prawie modelowym o handlu elektronicznym z 1996 r., zaś strukturalnie na konwencji wiedeńskiej z 1980 r. (CISG) odgrywa dość istotną rolę w handlu międzynarodowym, pomimo że jego stronami oficjalnie zostało jak dotąd jedynie 12 państw (wśród nich nie ma Polski) ${ }^{44}$. Konwencja obejmuje swoim zakresem umowy (rozumiane szeroko, w tym m.in. umowy arbitrażowe) międzynarodowe, których strony mają lokalizację w różnych państwach (niekoniecznie będących stronami konwencji), w sytuacjach, gdy prawo państwa będącego stroną konwencji jest prawem właściwym dla zawartej umowy, z wyłączeniem umów konsumenckich oraz transakcji związanych z niektórymi sektorami usług finansowych i przemysłu ${ }^{45}$. Poza definicjami wielu istotnych pojęć z obszaru komunikacji elektronicznej, konwencja dotyka również takich zagadnień, jak chwila wysłania oraz doręczenia wiadomości

43 United Nations Convention on the Use of Electronic Communications in International Contracts, http://www.uncitral.org/pdf/english/texts/electcom/06-57452_Ebook. pdf (dostęp 7 stycznia 2020 r.).

44 Stan na 7 stycznia 2020 r. Więcej jest jednak państw, które konwencję podpisały, lecz jeszcze nie ratyfikowały (np. Chiny), jak również takich, które deklarują przystąpienie do konwencji lub oparcie swojego prawa na jej postanowieniach (np. Kanada, USA czy Australia).

45 Por. szerzej J. GoŁACZyński, op. cit., s. 151, 152. 
elektronicznej. Akt zawiera ponadto zespół zasad, które odnoszą się między innymi do lokalizacji stron oraz wymogów informacyjnych (art. 6 i 7). Jedna z kwestii, jaką rozstrzyga konwencja, dotyczy posługiwania się adresem domeny lub poczty e-mail powiązanym $z$ określonym państwem. Artykuł 6 ust. 5 analizowanego aktu wskazuje, że na samej okoliczności takiego posługiwania się nie można oprzeć domniemania, jakoby miejscem siedziby strony było to właśnie państwo. Podobną rolę pełni art. 6 ust. 4, stosownie do którego nie jest miejscem siedziby miejsce, w którym zlokalizowany jest sprzęt oraz technologia wspomagające system informatyczny wykorzystywany w związku z zawarciem umowy, ani też miejsce, w którym system informatyczny może być dostępny dla innych stron. Artykuł 6 ust. 1 statuuje natomiast domniemanie, zgodnie z którym miejscem siedziby strony jest miejsce przez nią wskazane, chyba że druga strona wykaże, iż strona nie ma siedziby we wskazanym miejscu. Jeśli chodzi natomiast o osobę fizyczną niemającą siedziby, to stosownie do art. 6 ust. 3 konwencji uwzględnienia wymaga miejsce jej zwyczajnego pobytu (habitual residence). Warty wspomnienia postanowieniem konwencji jest również art. 8, który wyraża swoistą regułę antydyskryminacyjną poprzez wskazanie, że nie należy odmawiać ważności lub wykonalności umów tylko na podstawie tego, że zostały zawarte w toku komunikacji elektronicznej. Z regułą tą korespondują postanowienia art. 9 ust. 2 oraz 3, wskazujące, kiedy komunikacja elektroniczna oraz podpis elektroniczny spełniają przewidziany przez prawo właściwe wymóg pisemności. Podsumowując, wskazać należy w ślad za J. Gołaczyńskim, że konwencja dąży do osiągnięcia ponadnarodowego kompromisu oraz umożliwia przyjęcie takich samych (lub zbliżonych) zasad dotyczących wykorzystywania środków komunikacji elektronicznej w umowach międzynarodowych w systemach prawnych państw będących stronami konwencji ${ }^{46}$. 


\section{UWAGI KOŃCOWE}

Tytułem podsumowania wskazać trzeba, że problematyka prawa właściwego dla czynności prawnych dokonywanych w toku komunikacji elektronicznej ma charakter dwojaki. Z jednej strony czynności takie stanowią „normalne” czynności prawne i - pomimo całej swojej „technologicznej odrębności” - należy je rozpatrywać w świetle „tradycyjnych" ram prawnych. Z drugiej strony jednak nie sposób przejść do porządku dziennego nad związanymi z nimi trudnościami, takimi jak chociażby specyficzny i niejednolity mechanizm ustalania momentu wysłania oraz doręczenia wiadomości nadawanej w toku komunikacji elektronicznej. Potencjalnych rozwiązań dla tych oraz pokrewnych problemów na analizowanym obszarze poszukiwać należy przede wszystkim - jak trafnie zauważa J. Kulesza - w modernizacji prawa międzynarodowego prywatnego, harmonizacji praw krajowych, wykorzystaniu arbitrażu międzynarodowego oraz stosowaniu rozwiązań technicznych, które pozwoliłyby na określenie pochodzenia danych umieszczanych w Internecie $\mathrm{z}$ większą od obecnej pewnością ${ }^{47}$.

Jeśli chodzi natomiast o problematykę konfliktów jurysdykcji, wskazać należy, że kwestia ta - mimo iż stanowi zagadnienie pokrewne do tematyki poruszanej w niniejszym artykule - jest odrębnym obszarem, którego analiza wykraczałaby poza wytyczone ramy badawcze. Podstawowym aktem prawa wspólnotowego, do którego należy odesłać w tym zakresie, jest rozporządzenie w sprawie jurysdykcji i uznawania orzeczeń sądowych oraz ich wykonywania w sprawach cywilnych i handlowych ${ }^{48}$.

Tytułem uwag końcowych warto nadmienić jeszcze, że pojęcie prawa właściwego dla czynności (rozumianych szeroko, tj. m.in. oświadczeń woli, czynności prawnych, deliktów) podejmowanych w ramach komunikacji elektronicznej bywa odnoszone nie tylko do norm prawa krajowego, lecz także do innych systemów prawnych, w tym pozbawionych

47 J. Kulesza, op. cit., s. 179.

48 Rozporządzenie Parlamentu Europejskiego i Rady nr 1215/2012 z 12 grudnia 2012 r. (Dz. Urz. UE L 351 z 20 grudnia 2012 r., s. 1-32). 
mocy wiążącej. W ujęciu szerokim termin „źródeł prawa Internetu”49 - używany niekiedy wobec norm mających zastosowanie w stosunku do wszelkich podejmowanych drogą elektroniczną kroków prawnie doniosłych - odnoszony bywa również w odniesieniu do takich zbiorów regulacji i rozstrzygnięć, jak między innymi ponadnarodowe prawo modelowe, publiczne prawo międzynarodowe, orzecznictwo międzynarodowe (w tym rozstrzygnięcia arbitrażowe), modelowe umowy (np. umowy licencyjne typu General Public Licence), a nawet swoiste kodeksy postępowania (jak np. tzw. netykieta) oraz zwyczaj internetowy (traktowany niekiedy jako nowe lex mercatoria) ${ }^{50}$. Wyodrębnienie swoistego „autonomicznego prawa Internetu” jest jednak na obecnym etapie niemożliwe, choć można się spodziewać, że temat ten będzie powracał w przedmiotowej dyskusji z narastającą częstotliwością ${ }^{51}$.

\section{OŚWIADCZENIA WOLI SKŁADANE W TOKU KOMUNIKACJI}

ELEKTRONICZNEJ A PRAWO PRYWATNE MIĘDZYNARODOWE - ZARYS

PROBLEMATYKI

\section{Streszczenie}

Artykuł stanowi wprowadzenie do problematyki oświadczeń woli składanych w toku komunikacji elektronicznej rozpatrywanej w świetle obowiązujących w Polsce norm prawa prywatnego międzynarodowego. Ukazuje wpływ specyfiki elektronicznych środków porozumiewania się na postać oświadczenia woli oraz na zastosowanie norm kolizyjnych, zwracając uwagę na trudności mogące powstać na tym tle. Opracowanie opisuje zagadnienie ustalania prawa właściwego dla dokonania oraz dopuszczalności czynności prawnej, jak również problematykę wyboru prawa przez strony umowy. Artykuł referuje również tematykę ustalania prawa właściwego w sytuacji, gdy strony umowy opartej na elektronicznych oświadczeniach woli nie dokonały wyboru prawa (lub gdy wybór

49 Tyczy się to również innych sieci, urządzeń czy systemów, choć Internet stanowi rzecz jasna sieć dominującą, wskutek czego wiele terminów posługuje się jego nazwą.

50 Por. szerzej J. GoŁACZYŃski, op. cit., s. 22 i n.

51 Ibidem, s. 53. 
ten był niedopuszczalny). Tekst analizuje w przedmiotowym zakresie zarówno prawo polskie, jak i wybrane akty prawa międzynarodowego.

Declarations of Intent Made in the Course of Electronic Communication in the Light of International Private LaW: An OVERVIEW OF THE ISSUES

\section{Summary}

This article is an introduction to the issue of declarations of intent made in the course of electronic communication considered in the light of Polish private international law standards. It shows the impact of the specificity of electronic communication on the form of declarations of intent and on the application of conflict-of-law rules, pointing out the difficulties that may arise in this context. The study describes the determination of the law applicable to the performance and admissibility of a legal transaction, as well as the parties' choice of the applicable law. The article also addresses the determination of the applicable law in a situation where the parties to a contract based on electronic declarations of intent have not made a choice of law (or where a choice was inadmissible). The article considers both Polish law and selected acts of international law.

Słowa kluczowe: oświadczenie woli; prawo prywatne międzynarodowe; normy kolizyjne; komunikacja elektroniczna; umowy elektroniczne.

Keywords: declaration of intent; international private law; conflict of law rules; electronic communication, electronic contracts.

\section{Literatura}

GoŁACZYŃski J., Umowy elektroniczne w prawie prywatnym międzynarodowym, Warszawa 2007.

JANOWSKi J., Elektroniczny obrót prawny, Warszawa 2008.

Кот D., Zawarcie umowy za pomocą elektronicznych środków porozumiewania się na odległość (uwagi na tle projektowanych zmian kodeksu cywilnego), [w:] Zagadnienia prawa własności intelektualnej: Profesorowi Stefanowi 
Grzybowskiemu pracownicy Instytutu Wynalazczości i Ochrony Własności Intelektualnej $w$ darze, red. J. SADoK, Kraków 2002.

Konarski X., Komentarz do ustawy o świadczeniu usług droga elektroniczna, Warszawa 2004.

Kulesza J., Międzynarodowe prawo Internetu, Poznań 2010.

Lubasz D., Handel elektroniczny. Bariery prawne, Warszawa 2013.

Maciejewska-SzaŁas M., Forma pisemna i elektroniczna czynności prawnych. Studium prawnoporównawcze, Warszawa 2014.

Mankowski P., Das Internet im Internationalen Vertrags- und Deliktsrecht, «Rabels Zeitschrift für ausländisches und internationales Privatrecht» 2/1999, s. 203-294.

Marucha-Jaworska M., Podpisy elektroniczne, biometria, identyfikacja elektroniczna. Elektroniczny obrót prawny w społeczeństwie cyfrowym, Warszawa 2015.

PopioŁek W., Prawo właściwe dla umownych zobowiązań elektronicznych w konwencji rzymskiej i projekcie rozporządzenia Rzym I, [w:] Kolizyjne aspekty zobowiązań elektronicznych. Materiały z konferencji, red. J. GoŁACZYŃski, Warszawa 2008.

RadWAŃsKi Z., [w:] System prawa prywatnego. Prawo cywilne - część ogólna, II, red. Z. RADWAŃsKI, Warszawa 2008.

RadWAŃski Z., Teorie oświadczeń woli w świetle najnowszych zjawisk społecznych - komunikacji elektronicznej i ochrony konsumentów, [w:] Prawo prywatne czasu przemian. Księga pamiątkowa dedykowana Profesorowi Stanisławowi Sołtysińskiemu, red. A. Nowicka, Poznań 2005.

Szostek D., Czynność prawna a środki komunikacji elektronicznej, Kraków 2004.

Szostek D., wykład pt. Dokument elektroniczny w świetle nowelizacji przepisów k.c. $i$ k.p.c., http://notariat.pl/wiadomosci-notariat/353-dokument-elektroniczny-w-swietle-nowelizacji-przepisow-kc-i-kpc (dostęp 28 lutego 2020 r.).

Wejman F., Wprowadzenie do cywilistycznej problematyki ustawy o podpisie elektronicznym, «Prawo Bankowe» 2/2002, s. 37-52.

Wojewoda M., [w:] System prawa prywatnego. Prawo prywatne międzynarodowe, XX A, red. M. PAZDAN, Warszawa 2014.

ZACHARIASIEWICZ A.M., Zawarcie umowy $w$ drodze elektronicznej a prawo prywatne międzynarodowe, [w:] Kolizyjne aspekty zobowiązań elektronicznych, red. J. GoŁACZYŃski, Warszawa 2008. 